\title{
Den svenska trafikbrottsligheten
}

\author{
Av forskarassistent, jur. lic. HANS KLETTE
}

\section{Inledning.}

Kan man jämställa trafikbrottsligheten med den traditionella brottsligheten som t.ex. stöld, inbrott och dyl.? Svaret på den frågan beror naturligtvis på vad man menar med brott och brottsling. Man brukar försöka arbeta med antingen en juridisk eller en sociologisk definition. Enligt den juridiska definitionen är brott de beteenden som enligt lagstiftningen skall följas av straff eller annan påföljd. Att försöka ge ett svar på frågan med hjälp av denna definition är ej möjligt. I den sociologiska definitionen försökar man anknyta till samhällsmedlemmarnas uppfattning av vad som menas med brott och brottsling oberoende av vad lagen säger. Om den allmänna opinionen är överens om att ett beteende är antisocialt eller omoraliskt till en viss grad, kan det betecknas som brott. Problemet med denna definition är, att det inte råder någon överensstämmelse i den allmänna opinionen om vad som är antisocialt och omoraliskt och vad som menas med brott och brottsling. Från opinionsundersökningar vet vi nämligen, att allmänheten värderar skilda kriminella handlingar mycket olika. För att göra saken ännu mera förvillad kan vi konstatera att ordet brottsling inte alltid används, när ett brott i lagens mening har begåtts och handlingen även benämns brott av flertalet samhällsmedlemmar. Även bland polisen gör man dessa distinktioner. Detta märks framför allt i relation till trafikbrottsligheten, där polisen helt enkelt tycks spegla allmänhetens inställning. Man tycks alltså klart skilja mellan en traditionell brottslighet, där framför allt egendomsbrottsligheten är dominerande, och en ny brottslighet, där trafikbrottsligheten dominerar. Även bland de personer, som dömts för olika brott, märks samma reflex av samhällets inställning.

Trafikbrottsligheten har blivit föremål för få kriminologiska undersökningar. I Sverige finns endast några mindre, som jag skall återkomma till nedan. Men även i utlandet har denna typ av brottslighet starkt försummats av kriminologerna. Framför allt har inte försök gjorts att diskutera trafikbrottsligheten i relation till kriminologisk teori, vilket närmast beror på att vi vet alldeles för litet om denna brottslighet. Den engelske sociologen T. C. Willett har gjort den hittills utförligaste undersökningen av den grövre trafikbrottsligheten i boken „Criminal on the road". Av den tidigare litteraturen, vilken inte främst är kriminologisk utan mest berör olycksfallsundersökningar och då 
framför allt amerikanska, framgår enligt Willett, att personlighetsfaktorn är av störst betydelse. Bland såväl de grövre trafikbrottslingarna som förarna med hög olycksfallsbenägenhet fanns en stor procent av ,the maladjusted, the delinquent and the inadequate", och det är troligt att en hög procent av trafikbrottslingar inte skiljer sig i nämnvärd grad från den traditionelle brottslingen. Sambandet mellan social missanpassning samt hög olycksfallsbenägenhet och tidigare trafikbrott är också klart. Bland sociala bakgrundsfaktorer, som har samband med trafikbrottslighet enligt de tidigare undersökningarna, kan nämnas ålder, där åldersgruppen under 30 år är den dominerande liksom vid annan slags brottslighet med undantag dock för rattfylleristerna som är äldre, social klass och yrke, där antagandet att trafikbrottslingarna huvudsakligen skulle komma från högre samhällsgrupper avvisas, och där det framhålls att fördelningen tycks överensstämma med fördelningen inom allmän brottslighet, samt kön, där kvinnorna är lika klart underrepresenterade som inom allmän brottslighet (Se a.a.s. 40).

I det följande skall inledningsvis lämnas några uppgifter ur den officiella svenska statistiken för att belysa trafikbrottslighetens storleksordning som samhällsproblem. Därefter skall jag koncentrera mig på den grövre svenska trafikbrottsligheten, d.v.s. den som berörs av 1951 års trafikbrottslag. Först lämnas en redogörelse för lagstiftningen, därefter följer ett avsnitt om myndigheternas arbete och vissa viktiga beteenden, varpå lämnas några sociala bakgrundsvariabler beträffande trafikbrottslingarna. Avslutningsvis görs ett försök att anknyta till kriminologisk teori, och allra sist lämnas förslag på hur trafikbrottslingarnas beteende skall ändras.

\section{Trafikbrottsligheten som samhällsproblem.}

Vägtrafikrätten har blivit ett av de viktigaste områdena inom det moderna samhället, och trafikbrottsligheten är ett av de största inrikespolitiska problemen. Man får lättast en uppfattning om problemets storleksordning genom att se närmare på några grundläggande officiella statistiska uppgifter om trafiken och brottsligheten. (Se vidare SOU 1963: 27 och $\operatorname{KPr} 1966: 100$ ).

Motorfordonstrafikens starka ökning under 1950-talet har fortsatt också under 1960-talet. Antalet i centrala bilregistret införda motorfordon fyrdubblades således från 1950 till 1960 och var i mitten av 1966 omkring två miljoner eller sex gånger fler än 1950. Av dessa utgjorde personbilarna omkring $95 \%$ år 1966. Dessutom tillkommer omkring 70.000 motorcyklar, omkring 250.000 traktorer och omkring 700.000 mopeder, varför det sammanlagda antalet motorfordon utgör omkring tre miljoner år 1966. Öknin- 
gen av antalet motorfordon och den därmed stegrade trafikintensiteten, som kan uppskattas till omkring 8-10\% årligen, har medfört stora samhällsproblem, av vilka den kraftiga ökningen av antalet trafikolycker utgör det svåraste problemet. Enligt den officiella statistiken, som endast redovisar antalet polisundersökta trafikolycker, har dessa tredubblats från 1950 till 1962 och har sedan hållit sig konstanta med omkring 63.000 fall årligen. Som en jämförelse kan nämnas att antalet trafikskadefall, som anmäldes till trafikförsäkringsföretagen år 1965 var omkring 360.000 eller mer än sex gånger så stort som 1950. Vi ser också att sexdubblingen av antalet registrerade fordon $i$ bilregistret från 1950 till 1965 - 66 motsvaras av en sexdubbling av anmälda trafikskadefall. Dessutom ser vi att de av polisen undersökta trafikolyckorna endast utgör $1 / 6$ av de till försäkringsbolagen anmälda trafikolyckorna.

Samhället har genom en mängd olika trafikregler försökt öka trafiksäkerheten. Genom att undersöka antalet vägtrafikbrott enligt kriminalstatistiken bör man kunna få en grov måttstock på hur dessa trafikbestämmelser efterlevs. Vi skall då se, att med den växande trafiken har följt en i det närmaste motsvarande ölnning av antalet vägtrafikbrott. Antalet personer som fällts till ansvar för brott och förseelsen i trafiken var nämligen 1964 6-7 gånger så stort som 1950 eller 465.000 , varav 252.000 beivrats enligt lagen om parkeringsbot. Om man bortser från den senare lagen har en tredubbling av antalet för vägtrafikbrott ansvariga personer ägt rum från 1950 till 1964. Det bör också vara av intresse att uppmärksamma, att över $60 \%$ av samtliga till ansvar för brott fällda personer i landet under 1960-talet dömts för brott och förseelser i trafiken, varvid återigen bortses från lagen om parkeringsbot. Om den senare lagen tas med blir andelen beträffande trafikens andel av samtliga utdömda straff $70 \%$.

Vägtrafikbrotten fördelar sig på olika typer av förseelser. Antalet personer som fällts till ansvar för förseelse mot vägtrafikförordningen har varit omkring 170.000 årligen under åren 1962 1964. I dessa fall ingår endast dagsböter eller böter i straffskalan. Antalet personer som fällts till ansvar enligt trafikbrottslagen har varit omkring 45.000 årligen sedan slutet av 1950-talet. För majoriteten av dessa brott har fängelse ingått i straffskalan; efter den 1 juli 1966 är förhållandet dock ett annat, eftersom straffet för vårdslöshet i trafik numera endast är dagsböter. Dessutom tillkommer numera årligen omkring 12.000 andra trafikförseelser framför allt mot trafikförsäkringslagen samt det ovannämnda stora antalet fall av parkeringsbot, som 1964 uppgick till 252.000.

När man taler om den egentliga eller grövre trafikbrottsligheten, har man närmast i tanke brott mot trafikbrottslagen, varför i fortsättningen endast dessa brott skall beröras. 
Lagstiftningen beträffande trafikbrott.

1951 års lag om straff för vissa trafikbrott, som utgör den gällande lagstiftningen för den grövre trafikbrottsligheten, behandlar följande brott: vårdslöshet i trafik $(1 \S)$, hinder eller störning i trafik $(2 \S)$, olovlig körning ( $3 \S)$, rattfylleri (4 §) och smitning $(5 \S)$. I den föregående trafikbrottslagen från 1934 , som var vår första lag om trafikbrott, återfanns bestämmelser om ansvar för rattfylleri, grov vårdslöshet i trafik och smitning, medan trafikovarsamhet och olovlig körning hade behandlats i motorfordonsförordningen; någon direkt motsvarighet till $2 \S$ fanns inte $i$ tidigare svensk rätt. Före 1934 hade bestämmelserna om förseelser och brott i trafiken varit samlade i motorfordonsförordningar och dess föregångare, som går tillbaka till början av 1900-talet.

Enligt trafikbrottslagens $1 \S$ dömes för vårdslöshet $\mathrm{i}$ trafik till dagsböter, då vägtrafikant brister i den omsorg och varsamhet, som till förekommande av trafikolycka betingas av omständigheterna, och oaktsamheten inte är ringa. Där någon vid förande av vissa motorfordon ådagalägger grov oaktsamhet eller visar uppenbar likgiltighet för andra människors liv eller egendom, dömes för grov vårdslöshet $\mathrm{i}$ trafik till fängelse $\mathrm{i}$ högst ett år. Under 1960-talet har årligen omkring 25.000 personer fällts till ansvar enligt trafikbrottslagens 1 §. Av dessa har mindre än en procent dömts för grov vårdslöshet $\mathrm{i}$ trafik.

Om en vägtrafikant onödigtvis $\mathrm{i}$ väsentlig mån hindrar eller stör trafiken, straffas han, om inte gärningen är belagd med straff enligt $1 \S$, d.v.s. för vårdslöshet i trafik, med dagsböter enligt trafikbrottslagens $2 \S$. Denna bestämmelse kommer relativt sällan till användning, och antalet personer, som årligen fälls till ansvar enligt paragrafen, utgör troligen endast något hundratal.

Trafikbrottslagens $3 \S$ är däremot en oftare använd bestämmelse, och under 1950-talet har årligen omkring 13.000 personer fällts till ansvar enligt denna paragraf. Enligt lagregeln dömes för olovlig körning till dagsböter — lägst tio - om någon för ett körkortspliktigt fordon utan att vara berättigad därtill. Har han tidigare haft körkort, som blivit återkallat, eller har brottet skett vanemässigt eller är det i övrigt att anse som grovt, kan straffet bli fängelse $i$ högst sex månader. Vidare straffas enligt paragrafens 2 och 3 st. med dagsböter vid åsidosättande av vissa föreskrifter för körkort resp. vid tillåtande av olovlig körning. Dessa bestämmelser kommer också sällan till användning, och antalet personer, som årligen fälls till ansvar enligt dessa lagregler, utgör troligen endast något eller några hundratal.

Enligt trafikbrottslagens $4 \S$ dömes den som vid förande av motorfordon är olämplig att köra p.g.a. alkohol eller annat berusningsmedel för rattfylleri till fängelse i högst ett år eller vid mildrande omständigheter till dagsböter - lägst tjugofem. Om 
föraren av vissa motorfordon har en blodalkoholkoncentration av över 1,5 promille, anses han alltid vara olämplig. Om föraren inte dömes för rattfylleri, skall han straffas med dagsböter lägst tio - eller fängelse i högst sex månader, ifall hans blodalkoholkoncentration var mellan 0,5 och 1,5 promille vid körningen. Det senare brottet kallas vanligen rattonykterhet. Under 1960-talet har årligen omkring 8.000-9.000 personer dömts enligt trafikbrottslagens $4 \S$, varav omkring hälften vardera för rattfylleri och rattonykterhet.

Om en vägtrafikant genom att avlägsna sig från en olycksplats undandrar sig att i mån av förmåga medverka till de åtgärder, till vilka olyckan skäligen bör föranleda, eller om han undandrager sig att uppge namn och hemvist eller lämna upplysningar om händelsen, straffas han enligt trafikbrottslagens 5 \& med fängelse högst ett år eller dagsböter. Brottet benämnes obehörigt avikande från olycksplats m. m. eller vanligare smitning. Antalet personer, som fällts till ansvar för detta brott, har årligen hållit sig omkring 1.000 under 1960-talet.

Dessutom bör nämnas att de allmänna reglerna om medverkan i brottsbalkens 23 kap. 4 och $5 \S \S$ också är tillämpliga på trafikbrottslagen. Medverkan till trafikbrott utgör dock mindre än en procent av samtliga trafikbrott, varför de kan lämnas utanför diskussionen.

Straffet eller brottspåföljden har varit samhällets viktigaste medel för att avhålla motorfordonsförarna från brottslighet i trafiken, och vi kan konstatera, att man under hela 1900-talet varierat straffsatserna för att därigenom öka lagstiftningens effektivitet. I början av 1900-talet förekom endast böter i straffsatserna för trafikbrotten, men fängelse kunde ådömas för grov vårdslöshet redan från 1916 och ifall föraren varit berusad från 1923. Från 1930 var straffet också fängelse för trafikovarsamhet under försvårande omständigheter. I 1934 års trafikbrottslag förekom enbart fängelse för grov vårdslöshet. Normalstraffet för rattfylleri och smitning var fängelse, men vid mildrande omständigheter skulle dock dagsböter utdömas. 1951 blev straffsatsen dagsböter eller fängelse för vårdslöshet i trafik, fängelse eller dagsböter för smitning och för grov olovlig körning kunde fängelse utdömas. Den 1 juli 1966 borttogs så fängelse ur straffsatsen för enkel vårdslöshet $\mathrm{i}$ trafik. Villkorlig dom har redan från 1934 i regel inte ansetts vara lämplig vid brott enligt trafikbrottslagen.

Vid behandlingen av straffet eller brottspåföljden vid trafikbrott är det svårt att bortse från körkortsåterkallelserna, som visserligen inte räknas som ett straff utan som en skyddsåtgärd men som faktiskt upplevs som ett ytterst kännbart straff. Reglerna om återkallelse av körkort infördes på ett tidigt stadium i 
trafiklagstiftningens utveckling. De nuvarande bestämmelserna är från år 1958 och bestämmelserna om körkortsåterkallelse och varning återfinns i vägtrafikförordningens 33 och 34 §. Återkallelse är principiellt obligatorisk vid grov vårdslöshet $\mathrm{i}$ trafik, trafiknykterhetsbrott och smitning efter trafikolycka med personskada som följd. Från huvudregeln finns emellertid det undantaget, att vid mildrande omständigheter kan återkallelsen utbytas mot varning i det fall att förarens blodalkoholkoncentration understeg 0,8 promille under färden och föraren inte tidigare gjort sig skyldig till trafiknykterhetsbrott. Detta sker dock endast i några hundratal fall årligen. Om en motorförare genom upprepade förseelser mot trafik- och trafiksäkerhetsbestämmelser i väsentlig mån visat bristande vilja eller förmåga att rätta sig efter bestämmelserna, och om en motorfordonsförare på annat sätt i något för trafiksäkerheten väsentligt hänseende grovt åsidosatt honom såsom förare åliggande förpliktelser, kan återkallelse också ske. Det vanligaste är dock, att varning meddelas i dessa fall. Under 1960-talet har årligen omkring 8.500 körkortsåterkallelser skett och omkring 9.500 varningar meddelats. Av körkortsåterkallelserna har över hälften haft direkt samband med trafiknykterhetsbrott och omkring $2 / 3$ direkt samband med något trafikbrott. $\mathrm{Om}$ körkortsåterkallelse skett för grov vårdslöshet i trafik, får nytt körkort inte utfärdas inom två år och vid synnerliga skäl inom ett år. Vid körkortsåterkallelse p.g.a. övriga trafikbrott får nytt körkort utfärdas tidigast efter ett år eller vid synnerliga skäl tidigast efter tre månader.

\section{Material och metod.}

Undersökningsmaterialet består utöver de tillgängliga officiella statistiska uppgifterna främst av data om trafikbrottsligheten i Malmöhus län och Stockholm ur myndigheternas arkiverade akter. Dessa data är dels egna och dels sådana, som finns tillgängliga i stencilerade uppsatser i juridik från Lunds och Stockholms universitet samt i sociologi från Lunds universitet. Beträffande vårdslöshet $\mathrm{i}$ trafik har Holmqvist undersökt 600 misstänkta fall i Malmö 1964, Olofsson omkring 300 dömda personer i Lunds polisdistrikt 1962 och Grivenfeldt-Erviken 400 dömda personer i Stockholm 1963, beträffande olovlig körning har Olofsson undersökt ett 60 -tal dömda personer i Lunds polisdistrikt 1962, beträffande trafiknykterhetsbrott har Klette undersökt 4.500 misstänkta fall i Malmöhus län 1959-1965, FredholmSkagerberg 300 dömda personer i Stockholm 1964 och Olofsson ett 100-tal dömda personer i Lunds polisdistrikt 1962 samt beträffande smitning har Åberg undersökt 880 misstänkta fall i Malmö och Lunds polisdistrikt 1964. Dessutom har ett slumpurval av 700 personbilsförare i Malmöhus län intervjuats och 
besvarat enkät 1963 som ett led i mina egna undersökningar. Beträffande olovlig körning måste slutsatserna bli relativt osäkra, eftersom materialet är litet och säkerligen ej representativt; flertalet inte grova fall avgörs nämligen genom strafföreläggande, vilka ej medtagits. Bland undersökningsmetoderna bör också nämnas, att uppsatsförfattaren deltagit som participant observer bl. a. genom arbete under sammanlagt omkring $2 \frac{1}{2}$ år inom polisåklagar- och kronofogdemyndighet samt vid domstol.

\section{Myndigheternas arbete och beteende.}

Ifråga om myndigheternas beteende skall jag endast behandla två frågor närmare. Dessa berör upptäcktsproblemet d.v.s. främst polisens beteende, och påföljdsfrågan, d.v.s. främst domstolens beteende. Dessa båda problem måste anses vara två av de viktigaste faktorerna, som har samband med trafikbrottslagens effektivitet. Inledningsvis skall jag emellertid ge en kort översikt av myndigheternas arbetsbörda och den sorteringsmekanism, som de misstänkta fallen går igenom. Därvid skall de olika brotten skiljas åt.

Av den officiella statistiken såg vi att omkring 63.000 trafikolyckor blir föremål för polisundersökning årligen, men i jämförelse med dessa misstänkta fall såg vi, att endast omkring 25.000 personer dömes årligen. Av undersökningsmaterialet framgår att av ensamolyckorna avskrevs närmare $1 / 2$ av polisen och omkring $1 / 4$ av åklagaren, medan något över $1 / 4$ ledde till åtal, bland parkeringsskadorna var motsvarande siffor $85 \%, 15 \%$ och $0 \%$ och bland olyckor mellan minst två trafikanter i rörelse avskrev polisen över $40 \%$ av samtliga fall och åklagarna över $35 \%$, medan något över $20 \%$ ledde till åtal. Sammanlagt avskrevs alltså närmare $60 \%$ av alla fall av polisen, närmare $30 \%$ av åklagarna, medan mindre än $15 \%$ ledde till åtal. De dömdas andel är några procent mindre eller något över $10 \%$.

Vad beträffar olovlig körning finns endast uppgifter om antalet årligen dömda personer, som är omkring 13.000. Eftersom detta brott är synnerligen enkelt att konstatera, har troligen bortfallet från misstanke till dom varit minimalt.

Misstanke om trafiknykterhetsbrott förekommer till ett antal av omkring 15.000 årligen under 1960-talet, medan omkring $8.000-9.000$ personer döms enligt den officiella statistiken. Omkring $1 / 3$ av fallen skulle alltså försvinna från polisstadiet till domstolsstadiet. Ungefär $1 / 2$ av dessa fall avskrivs av polisen och $1 / 2$ av åklagaren, medan endast någon enstaka procent av åtalen ogillas av domstolen.

De misstänkta smitningsfallen utgjorde år 1965 enligt den offentliga statistiken 17.700 , medan de dömda utgjorde mindre än $7 \%$ av detta antal. I undersökningsmaterialet avskrevs över 
$85 \%$ av polisen, några procent av åklagaren, medan mindre än $10 \%$ ledde till åtal.

Av samtliga misstänkta trafikbrott stannar alltså något över $1 / 2$ på polisstadiet, omkring $1 / 3$ på åklagarstadiet, medan omkring $15 \%$ går till domstolens avgörande; omkring $7 \%$ av åtalen ogillas av domstolen.

Arbetsbördan av trafikbrottmål utgör omkring $1 / 2$ av arbetsbördan av brottmål vid underrätterna, och det finns anledning att anta, att arbetsbördan för polisens och åklagarens del är minst lika stor. Behandlingstiden från brottsupptäckt till dom är i genomsnitt omkring sex månader, av vilken tid något över hälften ligger på domstolsstadiet.

\section{Upptäcktsproblemet.}

En av de viktigaste faktorerna för att en lagstiftning skall verka effektivt är, att upptäcktsrisken är tillräckligt stor. Upptäckten är beroende av polisens eget beteende eller dess möjligheter att upptäcka brott och av allmänhetens beteende eller dess benägenhet att anmäla brott. Polisen upptäcker trafikbrotten främst under den allmänna trafikövervakningen, som också har ett preventivt syfte. Övervakningens stora betydelse att förebygga trafikolyckor framgår av försöken med förstärkt trafikövervakning. Faktorn har också betydelse för brottet vårdslöshet i trafik, därigenom att detta brott indirekt också förebyggs dels genom det minskade antalet trafikolyckor och dels genom att upptäcktsrisken för brottet utan samband med trafikolycka ökar. Likaså är trafikövervakningen av avgörande betydelse för att kontrollera att trafiksäkerheten inte minskas genom att motorfordonsförarna underlåter kravet på körkortsinnehav. Upptäckten av olovlig körning sker nämnligen till största delen genom den allmänna trafikövervakningen. För trafiknylkterhetsbrottens del är också övervakningsfaktorn av stor betydelse framförallt vid kontroll av mindre förseelser i trafik. Vi kan emellertid inte undersöka denna faktors betydelse närmare utan skall istället se något på upptäcktsrisken och upptäcktsituationen vid de olika trafikbrotten. Man bör i alla fall kunna konstatera, att även om trafikövervakningen ökat något efter förstatligandet av polisväsendet den 1 januari 1965 och speciellt då på huvudvägerna på landsbygden, torde det fortfarande vara ett mycket litet antal motorfordonsförare som kontrollerats av polisen. År 1963 hade $20 \%$ av de dagligen körande personbilförarna i Malmöhus län aldrig kontrollerats av polisen, $30 \%$ hade kontrollerats de senaste 12 månaderna, $40 \%$ de senaste 4 åren och $10 \%$ ännu tidigare.

Upptäckten av vårdslöshet $\mathrm{i}$ trafik sker nästan uteslutande $\mathrm{i}$ samband med trafikolycka, d.v.s. då skada inträffat. I undersökningsmaterialet hade någon form av skada inträffat i $90-95 \%$ 
av samtliga fall. Endast i omkring $5 \%$ av fallen har ingen skada inträffat, vilket betyder, att vårdslöshet i trafik, som enligt teorin är ett abstrakt farebrott, d.v.s. det krävs i princip inte att fara eller ens skada uppstått $\mathrm{i}$ det konkreta fallet, $\mathrm{i}$ praktiken är närmast ett effektdelikt. I varje fall upptäcks brottet nästan uteslutande, när en viss effekt inträtt. Detta beror på att polisens möjligheter att upptäcka brottet — både i och utan samband med trafikolycka - är små, och att allmänheten, som står för nästan samtliga fall av anmälan av trafikolyckor och därmed upptäckten av brottet, ytterst sällan anmäler någon motorförare för vårdslöshet $i$ trafik, som ej har samband med trafikolycka. Av undersökningsmaterialet framgår, att myndigheternas bedömning av graden av ovarsamhet huvudsakligen baseras på om eller hur stor skada, som inträffat. Det finns anledning att anta, att allmänheten också till betydande del låter skadans storlek vara avgörande för om en trafikolycka skall anmälas eller inte.

Vi konstaterade förut att endast $1 / 6$ av de till försäkringsbolagen anmälda trafikskadefallen blev föremål för polisundersökning. Redan detta tyder på att upptäcktsrisken för vårdslöshet i trafik är låg. Av undersökningsmaterialet från Malmö framgår, att de polisundersökta trafikolyckorna eller de misstänkta fallen av vårdslöshet $\mathrm{i}$ trafik består till $60 \%$ av olycka mellan minst två trafikanter i rörelse, till $33 \%$ av parkeringsskador och till $7 \%$ av ensamolycka. $1 / 3$ av samtliga fall var alltså anmälda som parkeringsskador, där det påkörande fordonet i flertalet fall ej påträffats. Ett flertal av dessa hade troligen gjort sig skyldiga till vårdslöshet $\mathrm{i}$ trafik. Detta förhållande gör, att det finns ytterligare anledning, att bedöma upptäcktsrisken för vårdslöshet $\mathrm{i}$ trafik som låg.

Olovlig körning är ett brott som till största delen upptäcks genom polisens allmänna trafikövervakning och främst genom rutinkontroll. En mindre del upptäcks också i samband med trafikolyckor och trafiknykterhetsbrott. Således har omkring $1 / 4$ av de, som döms för det senare brottet, också dömts för olovlig körning vid samma tillfälle. Allmänheten bidrar alltså ej till upptäckten av detta brott, och upptäcktsrisken måste bedömas som mycket låg.

Även vid trafiknykterhetsbrottet och framförallt vid rattonykterhet måste upptäcktsrisken bedömas som mycket låg. Av eget undersökningsmaterial framgår att omkring 5-9\% av samtliga faktiskt förekommande fall av personbilkörning med en antagen straffbar blodalkoholkoncentration upptäcktes. Den subjektivt upplevda upptäcktsrisken efter alkoholkonsumtion var hos genomsnittspersonbilföraren i medeltal 5 på 1000 eller $0,5 \%$ vid normal körning och 10 på 100 eller $10 \%$ vid något vinglig körning. Polisen upptäcker mindre än $1 / 3$ av personbilsrattfylle- 
risterna - främst i samband med mindre trafikförseelser - men över $3 / 4$ av mopedrattfylleristerna främst i samband med vinglig körning. Allmänheten upptäcker över $2 / 3$ av personbilsrattfylleristerna främst i samband med trafikolyckor, och genom anmälningar av förare som går till och från sina fordon och därvid visar yttre tecken på alkoholpåverkan. Även här är alltså allmänhetens medverkan av största vikt för upptäckten.

Smitning är ett brott, som nästan uteslutande anmäles av allmänheten. Det stora flertalet smitningsfall utgöres av fall med mịsstänkta okända förare. I undersökningsmaterialet på 880 misstänkta fall var omkring $87 \%$ fall med okända förare, där parkeringsskadorna var helt dominerande med omkring $90 \%$; över $80 \%$ av dessa var lätta fordonsskador. F.n. utgörs $30 \%$ av polisanmälda trafikolyckor i undersökningsmaterialet och enligt den officiella statistiken av misstänkta smitningsfall, och andelen torde komma att stiga under de kommande åren. Fallen med kända misstänkta hade anmälts av allmänheten och endast i några fall förekom självangivelse. Endast $7 \%$ av samtliga fall av misstänkt smitning i undersökningsmaterialet blev föremål för domstolsprövning. Denna andel tycks överensstämma med den officiella statistiken, där omkring 1000 personer årligen dömts för smitning under 1960-talet. Upptäcktsrisken för detta brott måste också bedömas som mycket låg.

\section{Brottspåföljden.}

För att en lagstiftning skall verka effektivt, är det också av största betydelse att brottspåföljden har effekt, d.v.s. att den dels kan avhålla presumtiva motorförare från att överträda trafikbrottslagens regler och dels kan påverka de motorförare, som redan överträtt reglerna, att i framtiden inte upprepa detta brottsliga beteende. Till brottspåföljden kan man inte bara räkna domstolens straffmätning utan också länsstyrelsens återkallelse av körkortet, eftersom även den senare åtgärden uppfattas och upplevs som ett straff av den som utsätts för det. Körkortsåterkallelsen kommer emellertid inte att behandlas här.

Domstolarna förlitar sig nästan uteslutende på att trafikbrottslagens effektivitet skall upprätthållas genom användning av bötesstraff. Av Brottsligheten 1961-1964 framgår att omkring $90 \%$ av de personer, som årligen fälls till ansvar enligt trafikbrottslagen, erhåller böter. Vi skall emellertid se, att det råder olika uppfattningar om vilken påföljd, som är effektivast, vid skilda trafikbrott.

Det vanligaste straffet vid vårdslöshet $\mathrm{i}$ trafik är 20 dagsböter, vilket tilldelats omkring $1 / 3$ av alla dömda, och det näst vanligaste straffet är 15 dagsböter, vilket omkring $30 \%$ erhöll. Omkring $45 \%$ erhöll mellan 10 och 19 dagsböter och lika många mellan 
20 och 29 dagsböter. Mindre än $10 \%$ erhöll högre än 30 dagsböter och där låg $1 / 2$ i gruppen $30-39$ dagsböter. Det tillhör alltså undantagen att dömas till över 40 dagsböter vid enkel vårdslöshet i trafik. Av Kriminalvården 1962-1965 framgår att de nytillkomna fängelsefångarna med vårdslöshet och grov vårdslöshet i trafik som huvudbrott årligen utgör omkring 160 st; i de flesta fall förekommer sälkerligen också ett eller flera bibrott i kombination. Det tillhör alltså också undantagen att komma i fängelse för brott mot trafikbrottslagens $1 \S$; mindre än $1 \%$ av samtliga dömda enligt denna paragraf erhöll detta straff.

Det tillhör även undantagen att komma i fängelse för brott mot trafikbrottslagens $3 \S$; även om fängelse är tre gånger vanligare här än vid brott mot $1 \S$. Vid olovlig körning förekommer endast böter i straffskalan. Huvudparten av de omkring 13.000 årligen dömda har också gjort sig skyldiga till enbart detta brott. Det vanligaste bötesstraffet är 25 dagsböter eller något däröver. Vid grov olovlig körning kan fängelse också utdömas enligt straffskalan. Det vanliga är emellertid, att grov olovlig körning första gången medför dagsböter — i regel $40-60$. Likaså utdöms vanligen dagsböter vid andra gångens olovliga körning — i regel omkring 70 - men vid tredje gångens olovlig körning följer i regel ett fängelsestraff på en månad, i vissa fall kanske $100-120$ dagsböter. Av Krimnalvården 1963-1965 framgår att de nytillkomna fängelsefångarna med brott mot trafikbrottslagens 3 § som huvudbrott årligen utgör omkring 425 st. - i flera fall förekommer säkerligen också bibrott i kombination — vilket betyder, att något över $3 \%$ av samtliga dömda enligt $3 \S$ erhöll fängelse.

Även vid smitning tillhör det undantagen att komma i fängelse. Av Kriminalvården 1962-1965 framgår att de nytillkomna fängelsefångarna med brott mot trafikbrottslagens $5 \S$ som huvudbrott årligen utgör omkring 5 st, vilket är endast omkring 1/2\% av samtliga dömda. Av undersökningsmaterialet framgår att det vanligaste straffet vid enbart smitning, vilket förekommer i omkring $1 / 3$ av samtliga fall, där smitning förekommer, är 30 dagsböter. Då smitning är kombinerat med vårdslöshet i trafik, vilket är fallet i likaså omkring $1 / 3$ av samtliga smitningsfall, blir straffet vanligen 50 dagsböter. Dessa straff gäller för relativt lindriga skador, och påföljden blir strängare vid allvarligare skador.

Av ovanstående framgår att endast $1,5 \%$ av samtliga dömda för brott mot trafikbrottslagens 1,3 och 5 §§ som huvudbrott erhåller fängelse; för brott mot $2 \S$ blir påföljden alltid dagsböter. Som kontrast till detta kan vi se på påföljden vid trafiknykterhetsbrott. Av Brottsligheten 1961 - 1964 framgår att omkring $1 / 2$ av samtliga dömda för brott mot trafikbrottslagens $4 \S$ som huvudbrott erhåller böter och omkring $1 / 2$ fängelse. Av Kriminalvården 1961-1965 ser vi, att de nytillkomna fängelsefån- 
garna med trafiknykterhetsbrott som huvudbrott årligen utgör omkring $3600-3700$ st, vilket betyder att $35-40 \%$ av de nytillkomna fängelsefångarna årligen utgöres av rattfyllerister. Vid rattfylleri blir straffet nästan undantagslöst fängelse och vid rattonykterhet nästan undantagslöst dagsböter. En viss hänsyn tas emellertid till slaget av motorfordon. En mopedrattfyllerist med en blodalkoholkoncentration under 2 promille får $\mathrm{i}$ regel också dagsböter. I övrigt är sambandet mellan brottspåföljd och blodalkoholkoncentration mycket starkt. Hänsyn tas också till den konkreta trafiksäkerhetsfaran vid straffmätningen. Av trafiknykterhetsbrottslingar med ovillkorligt fängelsestraff har $40 \%$ fått en månad, $45 \%$ två månader, $10 \%$ tre månader och $5 \%$ fyra månader och mera enligt Brottsligheten 1961-1964. Genomsnittsfängelsestraffet för trafiknykterhetsbrott — i praktiken mest rattfylleri - är således fängelse i en månad och femton dagar; genomsnittsfängelsestraffet är detsamma för de övriga trafikbrotten enligt samma statistiska källa. Genomsnittsbötesstraffet för trafiknykterhetsbrott - i praktiken mest rattonykterhet - ligger omkring 70 dagsböter. Detta betyder, att bötesstraffen i genomsnitt ligger omkring 50 dagsböter lägre vid vårdslöshet i trafik samt omkring 40 dagsböter lägre vid olovlig körning och smitning jämfört med vid trafiknykterhetsbrott. Man bör då observera, att smitning alltid och vårdslöshet i trafik nästan undantagslöst är brott, som medfört trafikolycka och skada ofta av svårt slag, medan trafiknykterhetsbrott i flertalet fall ej medfört skada. Samma anmärkning kan göras vid konstaterandet av den stora användningen av fängelsestraff vid trafiknykterhetsbrott till skillnad från vid övriga trafikbrott. I detta sammanhanget kan man också uppmärksamma, att villkorlig dom, som är ytterst sällsynt vid trafikbrott, endast förekommer $i$ en procent av frihetsstraffen vid trafiknykterhetsbrott mot i tre procent av frihetsstraffen vid övriga trafikbrott.

Man frågar sig naturligtvis, varför fängelsestraff användes vid trafiknykterhetsbrott men inte vid övriga trafikbrott? Det traditionella svaret är, att detta beror på allmänpreventiva skäl, d.v.s. andra motorförare än de straffade anses avhålla sig från körning $\mathrm{i}$ alkoholpåverkat tillstånd, då de vet att överträdelse av lagregeln kan medföra frihetsstraff. Men varför skulle inte samma gälla vid de övriga trafikbrotten?

\section{Trafikbrottslingarna.}

Vi skall nu se på några av de vanligaste personliga bakgrundsfaktorerna beträffande trafikbrottslingarna. I analysen har de fyra olika trafikbrotten hållits isär, men endast vissa större skillnader kommer att speciellt framhållas. 
Om vi först ser på den fordonstyp, som trafikbrottslingarna har använt, finner vi, att personbilarna är de dominerande med omkring $80 \%$, medan lastbilarna utgör omkring $10 \%$, mopederna omkring $5 \%$ och motorcyklarna omkring $2-3 \%$; de övriga fordonsslagen uppgår endast till några enstaka procent. Mopedförarna återfinns framförallt bland trafiknykterhetsbrotten, av vilka omkring $20 \%$ avser moped. Trafikbrottslingen kan alltså sägas vara en personbilsförare.

Även om trafiken internationaliseras kraftigt utgör dock de svenska medborgarna $90 \%$ av trafikbrottslingarna, medan $5 \%$ kommer från övriga nordiska länder och $5 \%$ från övriga länder.

Kvinnorna utgör en ungefär lika liten andel av trafikbrottsligheten som av den allmänna brottsligheten eller omkring $5-6 \%$. Men vid en speciell brottstyp, smitning, återfinns omkring $15 \%$ kvinnor.

Medelåldern för trafikbrottslingarna ligger strax under 30 år. Omkring $40 \%$ av samtliga är under 25 år mot omkring $2 / 3$ av samtliga strafflagsbrottslingar. För trafiknykterhetsbrotten är andelen under 25 år omkring $30 \%$ och för olovlig körning betydligt över $1 / 2$. Åldersgruppen mellan 25 och 39 år utgör över $1 / 3$ av alla trafikbrottslingar mot under $20 \%$ av samtliga strafflagsbrottslingar. Gruppen 40 år och äldre utgör alltså resten eller något över $1 / 4$ mot ungefär $1 / 8$ bland samtliga strafflagsbrottslingar. Det är framför allt trafiknykterhetsbrottslingarna och då främst mopedförarna, vilka återfinns bland den äldsta åldersgruppen; över $3 / 4$ av denna brottstyp utgöres av äldre mopedförare.

Civilståndstillhörigheten är en faktor, som varierar kraftigt bland de fyra slagen av trafikbrottslingar. Av samtliga är omkring $40 \%$ gifta, medan omkring $55 \%$ är ogifta och omkring $5 \%$ skilda. Vårdslöshet i trafik är det brott som mest överensstämmer med dessa siffror. Där återfinns omkring $45 \%$ gifta och omkring $55 \%$ ogifta, medan de skilda utgör endast en procent. Trafiknykterhetsbrottet skiljer sig däremot klart från genomsnittet vad beträffar de ej giftas andel. Medan de gifta utgör omkring $45 \%$ också vid detta brott, har de ogiftas andel sjunkit till under $40 \%$ och de skildas ökat till över $15 \%$. Speciellt att notera är att över $1 / 3$ av de skilda ändrat civilstånd under året förre brottet. Bland mopedförarna utgör de skilda över 1/3. Även olovlig körning och smitning skiljer sig kraftigt från genomsnittet. Här har de ogiftas andel ökat till över $2 / 3$ respektive $3 / 4$ och de giftas andel minskat motsvarande.

Det antas ofta, att trafikbrottslingar skiljer sig från brottslingar i allmänhet genom att de i genomsnitt har en högre social status, eller att de främst kommer från högre socialgrupper. Denna hypotes kan dock avfärdas. Omkring $2 / 3$ kommer nämligen från socialgrupp 3 eller arbetarklassen, omkring 1/4 från social- 
grupp 2 eller medelklassen och mindre än $10 \%$ från socialgrupp 1 eller överklassen. Bland yrkesgrupperna märks främst tillverkningsarbetarna - omkring $1 / 3$ - och transportarbetarna över $20 \%$. Det kan nämnas, att den största enskilda yrkeskategorien av samtliga är chaufförerna med omkring $20 \%$ bland vårdslöshet $\mathrm{i}$ trafik och $15 \%$ vid trafiknykterhetsbrott. Inkomsten bland trafikbrottslingarna ligger omkring $15.000 \mathrm{kr}$.

Körkort har inte funnits hos de körkortspliktiga förarna i omkring $10 \%$ vid vårdslöshet $\mathrm{i}$ trafik och omkring $25 \%$ vid trafiknykterhetsbrott. Omkring $1 / 2$ av körkortsinnehaven har varit mindre än 5 år och omkring $1 / 4$ mindre än 1 år. Något över $20 \%$ har haft körkort 5-9 år. Över $90 \%$ av körkortsinnehav under mindre än 5 år återfinns bland yngre än 25 år och lika stora andel av körkortsinnehav under mindre än 1 år återfinns hos yngre än 20 år.

Det har ofta antagits, att trafikbrottslingen till skillnad från den traditionella brottslingen, d.v.s. egendomsbrottslingen, är en respektabel samhällsmedborgare, som bortsett från enstaka trafikbrott eller trafikförseelser lever i överensstämmelse med samhällets regler. Denna hypotes visar sig emellertid vara felaktig. Omkring $15 \%$ av trafikbrottslingarna återfinns i kriminalregistret, där egendomsbrott och rattfylleribrott dominerar. För trafiknykterhetsbrottens del återfinns över $1 / 4$ i kriminalregistret och bland mopedförarna vid detta brott närmare $1 / 2$. Omkring $15 \%$ av trafikbrottslingarna återfinns i kontrollstyrelsens straffregister med registrering av fylleri eller trafiknykterhetsbrott under de tre senaste åren. För vårdslöshet i trafik är andelen mindre än $5 \%$ och för trafiknykterhetsbrottens del omkring $15 \%$ tidigare trafiknykterhetsbrott respektive fylleri. Andelen mopedrattfyllerister med tidigare fylleri är speciellt stor - omkring $2 / 3$. För olovlig körnings del är andelen dömda för grov olovlig körning med tidigare trafiknykterhetsbrott speciellt stor - omkring $1 / 2$. Omkring $1 / 2$ av trafikbrottslingarna återfinns $i$ körkortsregistret med någon registrering för trafikförseelse eller trafikbrott under de fem senaste åren. Omkring $1 / 2$ av dessa har $1-2$ registreringar, $1 / 43-4$ och $1 / 45$ och fler registreringar.

Det skulle nu vara möjligt att ge en grov bild av den svenske genomsnittstrafikbrottslingen med avseende på några sociala bakgrundsfaktorer. Först skall jag emellertid lämna vissa persondata om genomsnittspersonbilföraren för att en jämförelse skall kunna ske mellan de två förarkategorierna. Data om den senare gruppen har erhållits ur intervju — och enkätundersökningen med personbilsägarna i Malmöhus län.

Genomsnittspersonbilsföraren är en man, omkring 40 år gammal, gift, inkomst på omkring 25.000 kr., körkortsinnehav om- 
kring 12 år, bilägare omkring 7 år, folkskoleutbildad och tillhör socialgrupp 2 eller medelklassen.

Genomsnittstrafikbrottslingen är en man, strax under 30 år gammal, ogift, inkomst på omkring 15.000 kr., körkortsinnehav omkring $6-7$ år, folkskoleutbildad och tillhör socialgrupp 3 eller arbetarklassen.

\section{Brottspåföljdens verkningar.}

Som brottspåföljd $\mathrm{i}$ vidgad och icke juridisk-teknisk mening kan man vid trafikbrotten ha anledning att räkna inte bara bötesoch fängelsestraffet utan också körkortsåterkallelsen. Jag skall nu mycket kortfattat försöka redogöra för några av de sociala verkningar, som blir följden av trafikbrott.

Bötesstraffet utdömes $\mathrm{i}$ dagsböter. Brottets svårhetsgrad avgör antalet dagsböter, medan trafikbrottslingens ekonomiska förhållanden avgör storleken av dagsbotsbeloppet; meningen med dagsböter är ju, att de skall drabba lika hårt i förhållande till olika inkomsttagare och deras försörjningsförmåga. Genomsnittsårsinkomsten för trafikbrottslingarna låg omkring $15.000 \mathrm{kr}$. och det vanligaste dagsbotsbeloppet låg mellan 15 och $10 \mathrm{kr}$. Det genomsnittsliga antalet dagsböter var vid vårdslöshet $\mathrm{i}$ trafik 20 , olovlig körning 25 , trafiknykterhetsbrott 70 och smitning 30 . Bötesstraffen skulle då ligga på i medeltal omkring $200-300 \mathrm{kr}$. för vårdslöshet i trafik, $250-375 \mathrm{kr}$. för olovlig körning, $700-$ $1050 \mathrm{kr}$. för trafiknykterhetsbrott och $300-450 \mathrm{kr}$. för smitning. Några månader efter domen får trafikbrottslingen en anmaning av kronofogden att betala böterna. Dessa behöver emellertid inte erläggas omgående utan dels kan anstånd beviljas och dels kan avbetalning i särskilda poster medges. För de mindre bötessummorna sker inbetalning relativt omgående och på en gång. Det är dock mycket vanligt, att avbetalningsplaner på $1-2$ år med mer eller mindre månatliga belopp uppställs. Detta gäller framförallt vid de större bötessummorna d.v.s. främst vid trafiknykterhetsbrotten. I början av 1960-talet avbetalade de till böter dömda trafiknykterhetsbrottslingarna i Malmö och Lund sina böter med följande antal avbetalningar: $25 \% 1 \mathrm{ggn}, 10 \% 2 \mathrm{ggr}$, $15 \% 3-4$ ggr., $20 \% 5-9$ ggr. och $10 \% 10$ ggr. Återstoden -$20 \%$ - betalade aldrig sina böter. I dessa fall hade indrivningsförsök på böterna misslyckats, varför dessa böter avkortats -$10 \%$ - och avskrivits - $10 \%$. I de fall då böterna avkortats, hade böterna förvandlats till fängelse, vilket dock i praktiken innebär, att anstånd med verkställighet av förvandlingsstraffet beviljas med en prövotid på tre år.

Av det ovanstående torde framgå, att bötesstraffet för de $80 \%$, som slutligen erlägger hela bötessummen, ej torde utgöra några större ekonomiska påfrestningar, och ej torde få några större 
sociala verkningar. Vi kan också med intresse observera, att för $20 \%$ bortfaller brottspåföljden eller rättare att dessa $20 \%$ troligen upplever situationen så, att de inte fick något straff för sitt trafiknykterhetsbrott.

Det genomsnittsliga fängelsestraffet för trafikbrottslingarna är, som ovan framhållits, en månad och femton dagar. En viss allmän uppfattning om vad denna period i fängelse kan betyda får vi genom att se närmare på några av bakgrundsfaktorerna $i$ Brottsligheten 1961-1964 beträffande de ovillkorligt dömda trafikbrottslingarna.

Vad beträffar tidigare brottslighet framgår att omkring $1 / 2$ av trafikbrottslingarna tidigare sakfällts för kriminalregisterbrott, och att likaså omkring $1 / 2$ gjort sig skyldiga till fylleri och trafiknykterhetsbrott under de tre senaste åren; omkring $10 \%$ har blivit föremål för åtgärd enligt nykterhetsvårdslagen $i$ form av övervakning eller intagning på allmän vårdanstalt för alkoholmissbrukare. Dessa uppgifter tyder på en kraftig tidigare brottslighet och på betydande alkoholproblem i gruppen som helhet, varför man redan av denna anledning kan betvivla fängelsestraffets effektivitet. Beträffande tidigare kriminalregisterbrottslighet skiljer sig trafiknykterhetsbrottslingarna och de övriga trafikbrottslingarna kraftigt. Medan klart över $1 / 2$ av den förra gruppen inte sakfällts tidigare för kriminalregisterbrott, är förhållandet detsamma för endast $1 / 4$ av den senare gruppen. Om vi ser närmare på antalet gånger, som personerna sakfällts, finner vi, att i trafikbrottslingsgruppen som helhet har detta skett i $20 \% 1$ ggn., $10 \% 2$ ggr. och $20 \% 3$-ggr. Även här utgör övrige trafikbrottslingar ( = ej trafiknykterhetsbrottslingar) en speciell grupp, därigenom att närmare $1 / 2$ av dem har sakfällts 3 -ggr. Uppgifterna om antalet gånger, som personerna sakfällts, gör att man har ytterligare anledning att betvivla åtminstone den specialpreventiva effekten av fängelsestraffet.

Av de övriga bakgrundsfaktorerna enligt Brottsligheten bör nämnas civilstånd. Bland ovillkorligt dömda trafiknykterhetsbrottslingar är omkring $1 / 2$ gifta, över $1 / 3$ ogifta och $15 \%$ skilda och änklingar, medan motsvarande siffror för övriga ovillkorligt dömda trafikbrottslingar är $1 / 3$, över $1 / 2$ och närmare $15 \%$; de giftas andel är i klart sjunkande i båda brottsgrupperna. De tidigare ostraffade återfinns oftare bland de gifta än bland de övriga.

Av eget undersökningsmaterial framgick att återfallet bland tidigare ostraffade trafiknykterhetsbrottslingar — oberoende av om det aktuella straffet var böter eller fängelse - var omkring $6 \%$ under en treårsperiod. Det bör vara av speciellt intresse att undersöka hur ett enstaka ovillkorligt fängelsestraff verkar på en dömd ur denna socialt stabila grupp, på hans familj och 
sociala omgivning. För att försöka komma åt några av fängelsestraffets verkningar, valde jag, att intervjua 60 st. tidigare ostraffade bilägare, som dömts till $1-2$ månaders ovillkorligt fängelsestraff. Dessa intervjuades angående verkningarna på de områden, där konsekvenserna kunde antas bli störst, nämligen de civila arbetsförhållandena, ekonomin och de sociala relationerna. Bland verkningarna på de civila arbetsförhållandena och ekonomin kan nämnas att $94 \%$ av de intervjuade återvänder till sin gamla arbetsplats direkt efter fängelsevistelsen, medan de övriga byter arbete på egen begäran. Samtliga arbetstagare utom en sägs känna till att de intervjuade vistats på fångvårdsanstalt på grund av ett rattfylleribrott. $84 \%$ av arbetstagarna sägs ha visat sig ha en neutral inställning till detta förhållande; endast 2 har visat en direkt negativ inställning. Frånvaren från arbetet har möjliggjorts genom beviljad semester och tjänstledighet. Att ett fängelsestraff för trafiknykterhetsbrott ej har någon negativ inverkan på de civila arbetsförhållandena i form av svårigheter att få nytt arbete bekräftas också av intervjuundersökningen med normalbilförare. Över $90 \%$ påstod att de skulle anställa en person, som sökte arbete efter att ha avtjänat ett fängelsestraff för trafiknykterhetsbrott.

Genom att de undersökta fick återvända till sina gamla arbetsplatser påverkades inte ekonomin av det ovillkorliga fängelsestraffet mer än under själva fängelsevistelsen. De intagna har i medeltal en årsinkomst av omkring $\mathbf{1 5 . 0 0 0 ~ k r o n o r ~ o c h ~ f o ̈ r l o r a d e ~}$ i medeltal reellt 1200-1300 kronor per fängelsemånad. Strafftidens längd var i medeltal en månad och femton dagar, varför den ekonomiska förlusten p.g.a. fängelsestraffet kan beräknas till i medeltal 2000 kronor. Konsekvenserna av detta inkomstbortfall var inte alltför stora för de ogifta men desto kännbarare för de gifta, som utgjorde hälften av undersökningsmaterialet. I flertalet av dessa senare fall levde den hemmavarande familjen på besparingar, eller måste hustrun börja arbeta under mannens fängelsevistelse. Endast i ett fåtal fall måste de hemmavarande leva på socialhjälp.

Att de ekonomiska verkningarna av ett fängelsestraff blir större för de närmare $20 \%$ av trafikbrottslingarna, som enligt Brottsligheten 1961-1964 utgöres av företagare, än för de $2 / 3$ respektive $15 \%$, som utgör arbetare respektive tjänstemän, torde vara klart.

Bland verkningarna på de sociala relationerna kan nämnas att $66 \%$ trivdes bra eller ganska bra under fängelsevistelsen, medan $14 \%$ trivdes dåligt eller ganska dåligt; $20 \%$ sade sig trivas varken bra eller dåligt. Samtliga ansåg, att fängelsevistelsen ej skulle ha någon verkan på relationerna till vänner, bekanta och arbetskamrater. Dessa resultat bekräftas också av intervjuunder- 
sökningen med normalbilförare, av vilka över $95 \%$ påstod, att de skulle fortsätta att träffa en bekant, som suttit i fängelse för rattfylleri. Rattfylleristerna ansåg sig inte heller vara brottslingar av den vanliga typen som t.ex. egendomsbrottslingar och höll sig under fängelsevistelsen avskilda från övriga intagna. $74 \%$ av de hemmanhörande sades acceptera den intagnes fängelsevistelse. Av de övriga $26 \%$, som reagerade negativt, var samtliga hustrur till de intagna. Bland de $10 \%$ av fallen, där den intagne och hans hustru reagerade mycket negativt på fängelsevistelsen, finner vi samtliga fall, där de ekonomiska svårigheterna var stora och socialhjälp utgått.

De sociala verkningarna av fängelsestraff för trafikbrottslingarna minskas också genom den flitiga användningen av uppskov med verkställigheten av fängelsestraff för denna brottslingsgrupp. Enligt $12 \S$ lag om behandling i fångvårdsanstalt kan nämligen på ansöken av den som inte är häktad uppskov med verkställigheten av fängelse beviljas av länsstyrelsen under högst sex månader från den dag då domen kan verkställas, ,om med hänsyn till den dömdes hälsotillstånd eller yrkesutövning eller övriga förhållanden synnerliga skäl för uppskov prövas föreligga“. Dessutom kan Kungl. Maj:t av nåd bevilja ytterligare uppskov med verkställigheten av fängelsestraff. Under 19591960 ansökte omkring $1 / 2$ av alla i Malmöhus län boende ovillkorligt dömda trafikbrottslingar om uppskov med verkställigheten av fängelsestraffet. Majoriteten av dessa hade trafiknykterhetsbrott som huvudbrott, och $\mathrm{i}$ omkring $1 / 2$ av dessa fall beviljades uppskov av länsstyrelsen.

Det finns också ytterligare möjligheter för trafikbrottslingarna att $\mathrm{i}$ praktiken minska de sociala verkningarna av ett fängelsestraff. Ovannämnda lagparagraf stadgar nämligen också, att om någon dömts till fängelse och innan verkställigheten börjat visar att till Konungen ingivits nådeansökan om befrielse eller visst utbyte av straffet, skall med verkställigheten anstå $\mathrm{i}$ avvaktan på Konungens beslut, ifall personen ifråga inte är häktad och nåd inte tidigare sökts i målet. Denna möjlighet utnyttjas också av en betydande grupp trafikbrottslingar. Över $10 \%$ av de ovillkorligt dömda trafiknykterhetsbrottslingarna söker t.ex. årligen nåd. Vidare finns det möjlighet, att före domstolens i första instans dom vunnit laga kraft, d.v.s. inom tre veckor efter domslutet överklagar domen i hovrätten. Denna möjlighet utnyttjas likaså av en stor grupp trafikbrottslingar. Omkring $10 \%$ av de i första instans ovillkorligt dömda trafiknykterhetsbrottslingarna inom Svea Hovrätts och Hovrättens över Skåne och Blekinge domsområde överklagar t.ex. årligen sina domar $\mathrm{i}$ andra instans. Man kan också gå ett steg längre och försöka få prövningstillstånd i Högsta domstolen. Chanserna att få nådeansökan eller 
vadeinlagen bifallen eller att få prövningstillstånd är ytterst små, men genom de långa väntetider, som råder, innan avgöranden slutligen fattas, får de dömda ytterligare respittid med straffverkställigheten. Visserligen kan denna respittid inte exakt beräknas, men det finns dock goda möjligheter att manövrera så, att den slutliga straffverkställighetstiden förläggs till den för den dömde relativt sett mest lämpliga tiden, varigenom de sociala verkningarna av fängelsestraffet kan göras så små som möjligt.

Körkortsåterkallelsen uppfattas i praktiken också som ett straff eller en brottspåföljd. Effekten av denna påföljd måste naturligtvis vara ytterst olika beroende på vilket yrke den dömde har. I det egna undersökningsmaterialet av trafiknykterhetsbrottslingar från 1965 har jag försökt avgöra, hur beroende av körkortet, som de dömda varit i sin yrkesutövning. Till de direkt beroende måste främst räknas chaufförerna (12\%) - enligt Brottsligheten utgör motorfordonsförarna omkring $10 \%$ av de till kriminalregisterbrott dömda - och förmodligen också representanterna eller försäljarna $(3 \%)$, som starkt indirekt beroende kan räknas företagare, köpmän, lantbrukare, förmän, hantverkare $(17 \%)$ samt vissa specialarbetare som repartörer, elektriker o.dyl. och vissa hantverkare som målare, murare, snickare, plåtslagare, taktäckare o.dyl. (20\%). Dessa siffror, som får betraktas som endast approximativa och som minimisiffror, visar att $57 \%$ av de dömda är mer eller mindre beroende av körkort i sin yrkesutövning.

I den ovannämnda intervjuundersökningen av de till fängelse dömda trafiknykterhetsbrottslingarna försökte jag också undersöka körkortsåterkallelsens effekt på de civila arbetsförhållandena, ekonomin och de sociala relationerna. De intervjuade hade haft erfarenhet av i medeltal sex månaders körkortsåterkallelse. Beträffande verkningarna på de civila arbetsförhållandena kan framhållas att $30 \%$ hade tvingats byta arbete helt, och att ytterligare $30 \%$ hade förlorat goda arbetsmöjligheter inom arbetet p.g.a. körkortsåterkallelsen. Vad beträffar ekonomin kan nämnas att körkortsåterkallelsen på i medeltal sex månader hade medfört en genomsnittlig förlust av omkring $50 \mathrm{kr}$ per vecka. Om förlusten är konstant under de kommande två åren utan körkort skulle detta innebära ett inkomstbortfall på i medeltal $5000 \mathrm{kr}$. $42 \%$ förlorade dock inte någon inkomst alls p.g.a. körkortsåterkallelsen, medan istället förlusten för de övriga $58 \%$ blev desto större eller i medeltal närmare $100 \mathrm{kr}$ per vecka. Vilka konsekvenser körkortsåterkallelsen har på de sociala relationerna är svårt att avgöra. Som exempel på vad som blivit följden av körkortsåterkallelsen kan nämnas att $44 \%$ av de intervjuade förlorade i medeltal sex timmar per vecka genom att de inte själva kunde köra sin bil till och från arbetet. Vidare kan framhållas 
att i $30 \%$ av fallen fick dessutom någon annan familjemedlem mestadels frun - köra bilen vid dessa tillfällen. Att dessa förhållanden haft en viss negativ verkan på de sociala relationerna inom familjen bör kunna antas. Däremot har troligen körkortsåterkallelsen inte haft någon större verkan på de giftas fritid eller för de ogiftas sociala relationer, eftersom bilkörning som regel är en gruppföreteelse och någon annan i gruppen, som har körkort, kan ta hand om körningen, tills bilägaren innehar körkort igen.

Om vi jämför fängelsestraffets och körkortsåterkallelsens sociala verkningar, ser vi, att det förra inte haft någon verkan på de civila arbetsförhållandena, medan det senare haft en stor verkan för mellan $1 / 2$ och $2 / 3$ av samtliga trafiknykterhetsbrottslingar. Vi ser vidare, att körkortsåterkallelsen haft en betydligt större verkan på ekonomin än fängelsestraffet. För de intervjuade trafiknykterhetsbrottslingarna medförde den förra i medeltal 2,5 gånger större ekonomisk förlust än det senare.

\section{Kriminologisk teori och trafikbrottslighet.}

Kan man med hjälp av kriminologisk teoribildning ge någon förklaring till trafikbrottslingarnas beteende? Omkring $1 / 4$ av trafikbrottslingarna hade gjort sig skyldiga till brott, som ej hade samband med trafiken, omkring $1 / 4$ hade gjort sig skyldiga till trafikbrott och omkring $1 / 2$ hade inte gjort sig skyldiga till något brott, eventuellt någon enstakta trafikförseelse. Vi står nu inför den för kriminologen ofta återkommande frågan beträffande brottslingar: utgör de aktuella brottslingarna en minoritet med personlighetsavvikelser i samhället eller är det fråga om samhällsmedborgare utan personlighetsavvikelser men med anknytning till en avvikande eller brottslig miljö eller delkultur? Det finns inte undersökningsmaterial tillräckligt för att besvara den första delen av frågan, och vi måste därför avstå från att diskutera en psykiatrisk förklaring av trafikbrottsligheten. I stället kan vi inrikta oss helt på att försöka ge en sociologisk förklaring på problemet. På samma sätt som brottsliga delkulturer finns i samhället i stort, kan vi anta, att en brottslig delkultur återfinns bland vägtrafikanterna, som interagerar $i$ en del av samhällets sociala miljö. Det kan alltså antas, att trafikbrottslingarna bildar en av de många slagen av avvikande eller brottslige delkulturer som existerar i den moderna samhällsmiljön. (Se Willett a.a.s. $313 \mathrm{f}$ ).

Trafikbrottslingarnas delkultur kan delvis sammanfalla med andra kriminellas delkulturer. I dessa fall skulle man kunna anknyta till diskussionen om de brottsliga ungdomsgängens delkulturer med där rådande värderingar och normer, som kan ses som uttryck för försök att tillfredsställa behov och att lösa 
gemensamma personliga problem inom gruppen. Dessa tillfredsställs och löses i regel inte på annat sätt än genom främst negativistiska beteenden som t.ex. våldsbrott, skadegörelse och vårdslös körning.

Vi skall emellertid inte i första hand anknyta till denna aktuella kriminologiska teoribildning utan istället anknyta till en av de andra viktigare förklaringarna till brottsligt beteende, nämligen Sutherland's teori om differentiell association. Denna teori bygger vidare på Chicagoskolans slutsatser, att ungdomsbrottslighet främst sker i gäng, där det brottsliga beteendet lärs ut till nya medlemmar och förs vidare till nya generationer i gänget. Sutherland ville med sin teori förklara flera olika slags brottsliga beteenden bl.a. manschettbrottsligheten, som i många avseenden av flera anses ligga nära trafikbrottsligheten. Enligt teorin är brottsligt beteende inlärt i samspel med andra personer i en kommunikationsprocess, som huvudsakligen äger rum i primärgrupper. Inlärningen omfattar en speciell inriktning av attityder, rationaliseringar, behov, motiv och teknik, som läres från gynnsamma eller ogynnsamma definitioner av lagen. Den brottsliga inlärningsprocessen innehåller alltså samma mekanismer, som alla andra och icke-brottsliga inlärningsprocesser. (Se Sutherland-Cressey, Principles of criminology, s. $74 \mathrm{ff}$ ).

Man kan nu applicera Sutherland's tankegångar på trafikbrottsligheten och konstatera, att motorförarna lär sig sina körbeteenden $i$ och attityder till trafiken av andra motorfordonsförare. När flertalet motorförare överträder lagreglerna, blir det en stark press på den individuella föraren att också göra det. Gruppinfluensen är starkare än den allmänna trafikpropagandan. Bland ungdomarna, som har bilar, gäller t.ex. normen, att man skall köra, även om man inte har körkort. Likaså gäller t.ex. normen, att man skall köra fort. Om man inte gör det, uppmanas man hela tiden av de övriga i bilen att öka hastigheten. I båda fallen gäller, att om man inte lever upp till gruppnormen, blir man ansedd som feg och utesluts ur gruppen. Ett annat ex. är bilföraren, som vet att han har straffbar blodalkoholkoncentration men, i hopp om att inte upptäckas, tar chansen och kör, därför att de övriga gruppmedlemmarna anser det vara naturligt, att man kan köra säkert efter den konsumerade alkoholmängden. Grupptrycket upplevs i samtliga fall så starkt av individen, att han tvingas bete sig i överensstämmelse med gruppnormengruppbeteendet. Om han inte gjorde det, skulle han uteslutas ur gruppen, och därmed inte kunna tillfredsställa vissa av sina primära behov.

Med tillämpning av den aktuella teorin skulle förhållandet då vara det, att motorförarna, flertalet av vilka utgöras av helt normala medborgare, gav vika för brottsliga påtryckningar, när 
dessa användes. Frågan blir då, varför alla utom $1 / 4-1 / 3$ endast påverkades på trafikens område och inte på annat sätt. Ett svar på denna fråga skulle vara det, som Willett anser troligast, nämligen att överskottet av definitioner och då speciellt sociala sanktioner var ogynnsamt för en lagöverträdelse på andra områden men gynnsamt på trafikens område. Därigenom fann ett latent brottsligt beteendemönster sitt utlopp på ett område, där omständigheterna var gynnsamma. Med denna förklaring skulle alltså trafikbrottslingarna ej skilja sig från andra brottslingar i sin inställning till samhällets lagstiftning. (Se Willett a.a.s. 315).

\section{Hur förändrar man trafikbrottslingarnas beteende?}

Sutherlands differentiella associationsteori är också av intresse beträffande trafikbrottslingarnas behandling. Han underströk kraftigt det meningslösa i att döma människor till böter, fängelse eller något annat straff och sedan låta dem återvända oförändrade till samma kriminella miljö, som var grogrunden för brottsligheten. Men detta är vad som händer undantagslöst beträffande trafikbrottslingarna. Om någon förändring av deras beteende skall kunna åstadkommas, är det nödvändigt att se till att de får kontakt med laglydiga grupper, som de kan identifiera sig med på något plan. Willett föreslår speciell gruppundervisning i körning och trafiksäkerhet för trafikbrottslingarna, där de kan kritisera andras körbeteende och få sitt eget kritiserat. (Se Willett a.a.s. 316). Detta kan sägas motsvara den form av gruppterapi, som användes försöksvis inom bl.a. kriminalvården. Genom att till gruppledare välja personer med hög status — t.ex. professionella motorförare, underhållare, idrottsstjärnor eller andra - kan vidare en trafiksäkrare körnorm infiltreras i gruppen. Det viktiga är nämligen, att det är grupptrycket, som skall ändra individens attityd och beteende. Vi kan också se på problemet från samma socialpsykologiska utgångspunkt men i hela samhällets perspektiv. Den kultur, där den brottsliga delkulturen ingår, d.v.s. det motorfordonsförarsamhälle av vilket trafikbrottslingarna utgör en del, måste försöka förändra attityd och beteende hos denna typ av lagöverträdare — både registrerade och icke-registrerade - så att dess behov inte längre tillfredsställs av brottsliga normer utan av normer, som innebär ett trafiksäkerhet körsätt. Här er det främst den allmänna opinionens uppgift att vara verksam.

För att studera trafikbrottslagens verkningar eller effekten av de olika faktorer, som kan antas påverka den individuella motorfordonsförarens körbeteende, kan användas bredvidstående begreppsschema, som redan använtes av uppsatsförfattaren för att studera trafiknykterhetslagstiftningen. Detta schema skall användas i framtida undersökningar beträffande samtliga brott i 
trafikbrottslagen. Därvid kommer speciellt intresse att ägnas gruppnormen, som kan antas vara den betydelsefullaste faktorn i sammanhanget.

Hans Klette.

Hans Klette: Begreppsschema eller modell för undersökning av lagstiftningens generalpreventiva verkan eller den legala påverkningsprocessen.

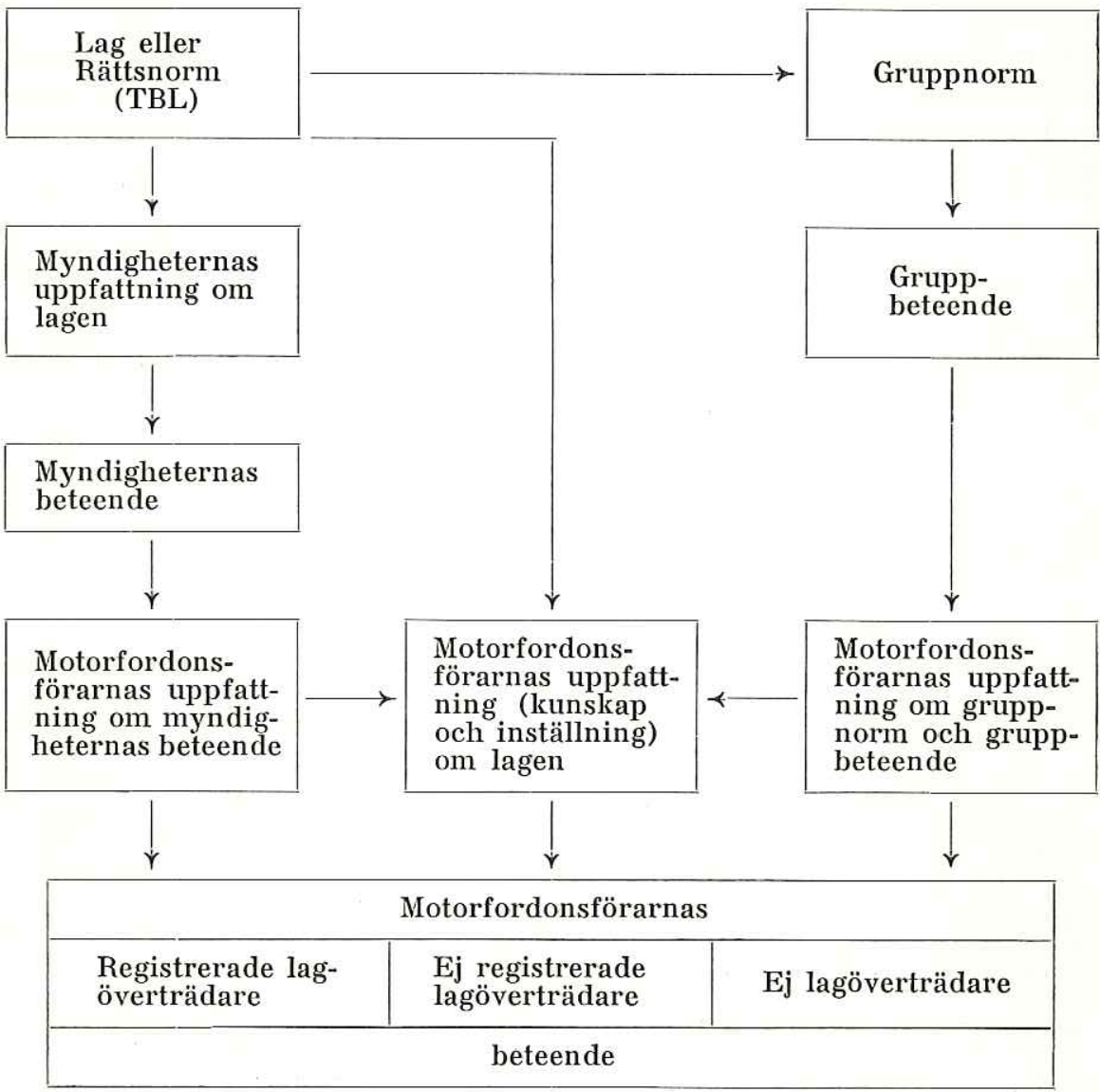

